\title{
Feasibility Studies of Using the Catfish Immune System to Produce Monoclonal Antibodies
}

T. M. Poston

March 1987

Prepared for the U.S. Army under a Related Services Agreement with the U.S. Department of Energy Contract DE-AC06-76RLO 1830

Pacific Northwest Laboratory Operated for the U.S. Department of Energy by Battelle Memorial Institute 


\section{DISCLAIMER}

This report was prepared as an account of work sponsored by an agency of the United States Government. Neither the United States Government nor any agency thereof, nor Battelle Memorial Institute, nor any of their employees, makes any warranty, expressed or implied, or assumes any legal liability or responsibility for the accuracy, completeness, or usefulness of any information, apparatus, product, or process disclosed, or represents that its use would not infringe privately owned rights. Reference herein to any specific commercial product, process, or service by trade name, trademark, manufacturer, or otherwise, does not necessarily constitute or imply its endorsement, recommendation, or favoring by the United States Government of any agency thereof, or Battelle Memorial Institute. The views and opinions of authors expressed herein do not necessarly state or reflect those of the United States Government or any agency thereof, or Battelle Memorial Institute.

\section{PACIFIC NORTHWEST LABORATORY operated by \\ BATTELLE MEMORIAL INSTITUTE \\ for the \\ UNITED STATES DEPARTMENT OF ENERGY \\ under Contract DE-AC06-76RLO 1830}

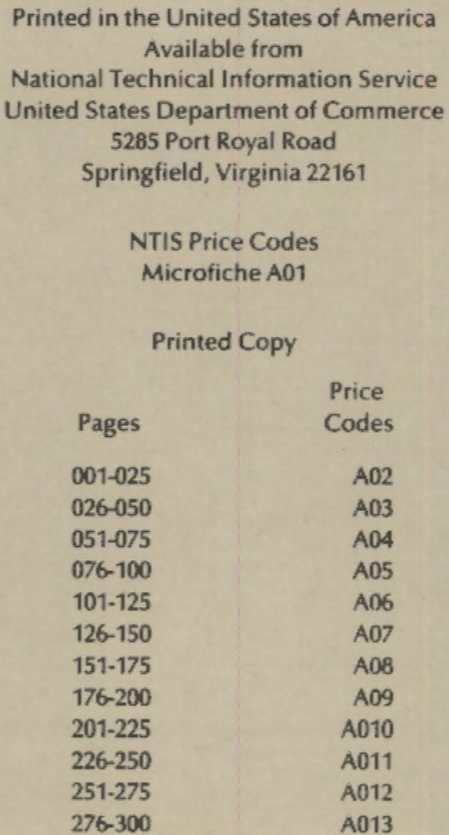


FEASIBILITY STUDIES OF USING THE CATFISH IMMUNE SYSTEM TO PRODUCE MONOCLONAL ANTIBODIES

T. M. Poston

March 1987

Prepared for

the U.S. Army Chemical Research, Development, and Engineering Center Aberdeen Proving Ground under a Related Services Agreement with the U.S. Department of Eneray Contract DE-AC06-76RLD 1830

Pacific Northwest Laboratory

Richland, Washington 99352 
,

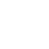




\section{SUMMARY}

The objective of these studies was to determine the feasibility of using a teleost cell line to produce monoclonal antibodies. Studies were undertaken to demonstrate the production of a polyclonal response of channel catfish (Icatalurus punctatus) challenged with mycotoxins coupled to a protein carrier. Companion studies were also performed to induce a permanent cell line with catfish lymphocytes. Attempts to demonstrate a polyclonal response to haptenized mycotoxins were inconclusive. Tests to induce an immortal, permanent cell line with benzene and $x$-ray irradiated cells were also inconclusive. 
, 
CONTENTS

SUMMARY ............................

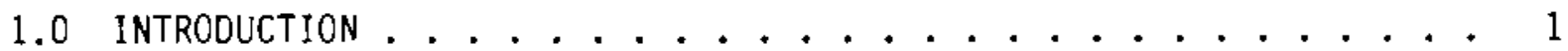

2.0 INDUCTION OF ANTIBODIES AGAINST OCHRATOXIN ......... 3

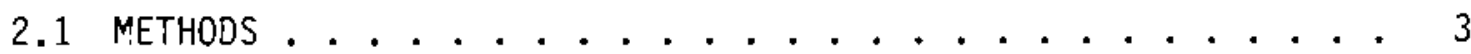

2.1.1 Catfish Vaccination and Preparation of Vaccine... . 3

2.1.2 Sampling of Catfish Serum .......... 3

2.1.3 Enzyme-Linked Immuno Sorbant Assay . . . . . . . . 4

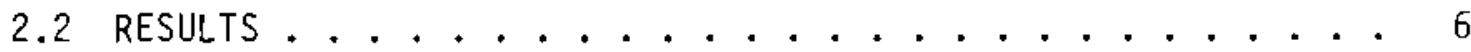

2.2 .1 Screening ELISA ............ 6

2.2.2 Carbodi imide BSA ............. 7

3.0 INDUCTION OF ANTIBODIES AGAINST T2 TOXIN .......... 12

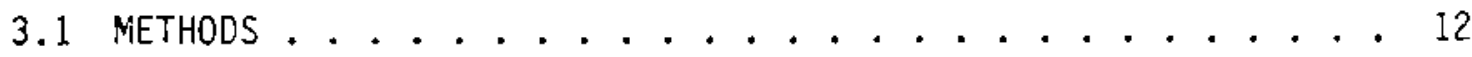

3.1.1 Catfish Vaccination and Preparation of Vaccine . . . 12

3.1 .2 Sampling of Catfish Serum ......... 13

3.1.3 Enzyme-Linked Immuno Sorbant Assay . . . . . . . 13

3.1.4 ELISA for T2-Specific Antibodies ........ 15

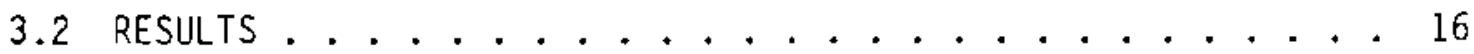

3.2 .1 Screening ELISA . . . . . . . . . 16

3.2.2 ElISA for T2-Specific Antibodies . . . . . . . 17

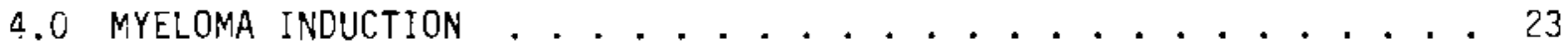

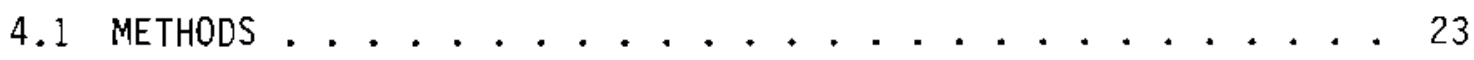

4.1.1 Channel Catfish ............ 23

4.1.2 Sampling and Culture of Spleen and Kidney Cells . . 23

4.1 .3 Benzene Exposures . . . . . . . . . . . . . 24 
4.1.4 Pristane Exposures .............. 29

4.1.5 In vitro Exposures............... 29

4.2 RESULTS . . . . . . . . . . . . . . . . . 30

4.2.1 In vivo Exposures .............. 30

4.2.2 In vitro Exposures ............... 32

5.0 CONCLUSiONS AND RECOMMENDATIONS. . . . . . . . . . . . . 37

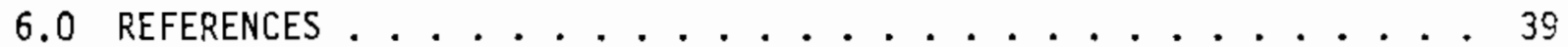




\section{TABLES}

1. ELISA Control Treatments for OA-BSA Immunized Catfish . . . . 8

2. Absorbence Values for Catfish Serum Samples Analysed with ELISA for the Detection of OA Specific Antibodies . . . . . . . . . 10

3. Difference in Absorbence Values for Catfish Serum Samples Analysed with ELISA for Detection of OA Specific Antibodies . . . II

4. Combined Growth of Experimental Fish, T2-BSA-Vaccinated Fish and BSA-Vaccinated Fish................ 15

5. Absorbence Values from ELISA of Rabbit IgG, BSA, Catfish-antiBSA, and Rabbit-anti-catfish IgG . . . . . . . . . . 19

6. ELISA for Other Reagents to be Used in Assays for T2-Specific Antibodies in Immune Catfish Serum . . . . . . . . . . . 20

7. Initial ElISA of Four Catfish Sera on Plates Precoated with $\mathrm{T} 2-\mathrm{KLH}$ and $\mathrm{KLH} . . . . . . . . . . . . . . . . .21$

8. Effect of Gelatin Blocking Agent on ELISA of Immune Catfish Serum in Wells Precoated with T2-KLH and KLH ........ 22

9. ELISA of Catfish Immunized Against T2-BSA and BSA. . . . . . 23

10. Distribution of Cell Types in Benzene-Exposed Catfish . . . . . 31

11. Comparison of Cell Counts Made by Technician No. 1 and No. 2 from the Same Slides... . . . . . . . . . . 32

12. Peritoneal Sampling of Pristane- and Pristane/Benzene-Injected Catfish. . . . . . . . . . . . . . . . 33

13. Blood Cell Distribution of Catfish Exposed to Benzene, Exposed to Benzene and Injected with Pristane, and Control Fish. . . . . . 34 


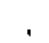

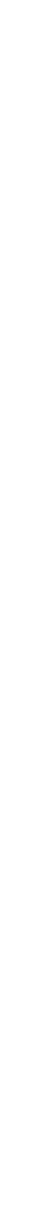




\subsection{INTRODUCTION}

The development of Enzyme-Linked Immuno Sorbant Assays (ELISA) has provided a highly specific and sensitive method for detecting imanogenic compounds. The technology has further application to nonimmunogenic compounds provided that the compounds can be coupled to a larger immunogenic carrier compound (i.e., a hapten-carrier complex). Hapten-carrier complexes may be produced with mycotoxins of low molecular weight and larger protein molecules. This application is of particular interest to the Chemical Research, Development, and Engineering Center (CRDEC), U.S. Department of Defense because of the potential use of mycotoxins for biological war agents. Trichothecenes (T2 toxin) and ochratoxin are two funga $i$ toxins that may be used as biological war agents. It is imperative that military personnel be able to determine the presence of these toxins in the field. ELISA may provide the technology for development of a simple test system for detecting mycotoxins in environmental samples in the field.

The ability to produce large amounts of reagents for producing field test kits depends on the mass production of highly specific monoclonal antibodies against the mycotoxin. Monoclonal antibodies are currently produced with plasmacytomas developed from BALB/C mice. These antibodies are usually of the dimeric IgG class of immunoglobulin. Other systems have not yet been developed for the production of monoclonal antibodies. The use of freshwater teleosts to develop and produce monoclonal antibodies may confer advantages over monoclonal antibodies produced with the BALB/C mouse system. Teleost antibodies assume a tetrameric configuration that may lead to increased sensitivity and possibly greater longetivity of shelf reagents. Deveioping an alternative system for producing monoclonal antibodies in freshwater teleosts may result in better reagents.

Some questions need to be resolved before monoclonal antibodies can be produced in teleosts. Initially, it must be demonstrated that teleosts can produce specific antibodies against haptenized mycotoxins. In order to proceed with hydridization of antibody-producing teleost lymphocytes, a suitable immortal cell line must be developed that is compatible with the fish lymphocyte and with current fusion techniques. 
This report summarizes exploratory research that has been conducted at Pacific Northwest Laboratory (PNL) on the production of specific antibodies against haptenized mycotoxins. Chapters 2 and 3 contain disusssions of studies dealing with the attempted induction of antibodies against ochratoxin haptenized to bovine serum albumin and $T 2$ toxin, respectively. Chapter 4 contains a discussion of the attempt to induce an immortal myelogenous celt line for use as a fusion partner. The research is summarized and research recommendations are made in Chapter 5. 


\subsection{INDUCTION OF ANTIBODIES AGAINST OCHRATOXIN}

An experiment was performed to determine if antibodies against ochratoxin could be induced by vaccinating channel catfish with the mycotoxin conjugated to bovine serum albumin (OA-BSA). The experiment involved the vaccination of four groups of channel catfish: 1) five control fish, 2) three fish sham injected with Freund's Complete Adjuvant (FCA), 3) two catfish injected with $100 \mu \mathrm{g} O A-B S A$ in FCA, and 4) four catfish injected with $50 \mu \mathrm{g}$ OA-BSA in FCA (14 total fish). The standard length of the experimental catfish was $8.5 \pm 0.7 \mathrm{~cm}$. The fish weighed $7.02 \pm 1.94 \mathrm{~g}$ when the serum was sampled. ELISA was used to analyze serum samples for specific antibody activity.

\subsection{METHODS}

\subsubsection{Catfish Vaccination and Preparation of Vaccine}

Catfish used for this study were purchased from Dale Fattig (Brady, NB) in August 1984 . The fish were held at $24^{\circ} \mathrm{C}$ for the duration of exposure.

Ochratoxin-BSA conjugate was obtained from Sigma Chemical Company (St. Louis, MO). Five milligrams were taken up in $2.5 \mathrm{~mL}$ of phosphatebuffered saline (PBS) (PH 7.16). The OA-BSA was mostly insoluble. The material was mechanically dispersed with a glass rod and a pasteur pipet and transferred to dialysis tubing. The preparation was dialyzed for 24 hours in $900 \mathrm{~mL}$ PBS at about $4^{\circ} \mathrm{C}$. The dialyzed solution was stored in darkness at about $4^{\circ} \mathrm{C}$ until it was used to prepare the vaccine or the ELISA. The vaccine consisted of a $1: 1$ emulsification of Freund's Complete Adjuvant (Sigma) and OA-BSA in PBS. Fish were vaccinated with either 0.05 or $0.1 \mathrm{~mL}$ of emulsion that contained nominal concentrations of $50 \mu \mathrm{g}$ and $100 \mu g$ of OA-BSA, respectively.

\subsubsection{Sampling of Catfish Serum}

At 40 days post vaccination, the experimental fish were anesthetized with MS-222 (Argent Chemical Co., Redmond, WA). Blood was obtained from 
the fish by severing the caudal peduncle. The blood was collected in 0.4-mL micro-centrifuge tubes. After the biood samples were incubated on ice for about 1 hour, they were centrifuged for 3 minutes with a Beckman Model 152 Micro-centrifuge. The serum was transferred to a clean centrifuge tube, capped, and frozen at $-80^{\circ} \mathrm{C}$ until assayed.

\subsubsection{Enzyme-Linked Immuno Sorbant Assay}

ELISA methods followed the basic approach of Voller, Bidwell, and Bartlett (1979). Immulon-2 plates were precoated with BSA and OA-BSA for the application of ELISA. A screening assay and a compiete assay of fish sera incorporating a modification of the basic ELISA methodology were completed.

\subsubsection{Reagents}

The reagents used for this study were obtained from Sigma Chemical Company and included: goat*-anti-rabbit alkaline phosphatase conjugate, bovine serum albumin, p-nitro-phenyl phosphate, ochratoxin-bovine serum albumin conjugate, and giycine. Rabbit-anti-catfish IgG was provided by Dr. Craig Lobb of the University of Southern Mississippi. The crosslinking reagent 1-ethyl-3-(3-dimethylamino)propyl-carbodilmide was purchased from Alfa Chemical Company (Danvers, MA).

\subsubsection{Screening ELISA}

Screening tests were performed to evaluate cross reactivity among reagents and to determine the working concentrations of reagents.

An initial screening assay was performed with sera from a shamvaccinated catfish (0.1-mL FCA and physiological saline) and a catfish that had been vaccinated with $50 \mu \mathrm{g}$ of OA-BSA. Wells in Immulon-2 plates were coated for 24 hours with either BSA or OA-BSA at a concentration of $0.2 \mu \mathrm{g} / \mathrm{mL}$ in carbonate buffer. Protein concentrations for the OA-BSA were determined by UV absorbence at $280 \mathrm{~nm}$ against a BSA standard. The OA-BSA would not completely dissolve in distilled water, so the solution was centrifuged $(70 \times \mathrm{g})$ for 5 minutes to remove undissolved fragments of OA-BSA. The absorbence for the resulting supernatant diluted 1:10 was 
0.042 , compared to 0.555 absorbence for a standard BSA solution of $1000 \mu \mathrm{g} / \mathrm{mL}$. One-tenth of $5 \%$ catfish sera was tested in duplicate wells. One percent gelatin incubated for 96 hours was used as a blocking agent. Phosphate-buffered saline with a detergent $10.05 \% \mathrm{v} / \mathrm{V}$ Tween 20 , hereafter designated PBST) was used to rinse wells between the addition of reagents. The following sequence of events describes the screening assay:

1. added catfish sera for 1 hour

2. rinsed $3 x$ with PBST and added rabbit-anti-catfish IgG for 1 hour

3. rinsed $3 x$ with PBST and added goat*-anti-rabbit IgG for 1 hour

4. rinsed $3 \times$ with distilled $\mathrm{H}_{2} \mathrm{O}$ and added enzyme substrate $1.0 \mathrm{mg} / \mathrm{mL}$ p-nitrophenyl phosphate in $0.1 \mathrm{M}$ glycine buffer, $0.001 \mathrm{M} \mathrm{MgCl}_{2}$, $0.001 \mathrm{M} \mathrm{ZnCl}_{2}, \mathrm{pH} \mathrm{10.4)}$ for 25 minutes at room temperature

5. teminated the reaction by adding $3 \mathrm{~N} \mathrm{NaOH}$.

Absorbence at $405 \mathrm{~nm}$ was measured in a Beckman DB25 Spectrophotometer by combining the contents of duplicate wel1s. Control treatments were set up with the blocking agent only and the blocking agent less the addition of rabbit-anti-catfish $I g G$.

\subsubsection{Carboditimide BSA}

The BSA was treated by the methods used for OA-BSA conjugation (Chu, Chang, and Hinsdill 1976) to detemine background levels of activity in the sera. All catfish sera were tested in wells precoated with BSA, carbodijmide-treated BSA (BSA-CARB), and OA-BSA conjugates.

Two Immulon-2 plates (designated A and B), each with 96 wells, were used for the following treatments:

1. columns 1 and 2 , received carbonate buffer only

2. columns 3 and 4 , received $0.2-\mathrm{mL} B S A(0.2 \mu \mathrm{g} / \mathrm{mL})$

3. columns $5,6,9$, and 10 , received $0.2-\mathrm{mL}$ OA-BSA $(0.2 \mu \mathrm{g} / \mathrm{mL})$

4. columns $7,8,11$, and 12 , received $0.2-\mathrm{mL}$ BSA-CARB $(0.2 \mu \mathrm{g} / \mathrm{mL})$.

The plates incubated at $4^{\circ} \mathrm{C}$ for 3 days with the coating solutions. Prior to adding sera, a blocking agent ( $1 \%$ gelatin in carbonate buffer) was 
added to both plates for an additional 3 days at $4^{\circ} \mathrm{C}$. Each well was rinsed three times with PBST before each of the following steps.

1. Added $100 \mu \mathrm{L}$ serum. The serum was diluted from $5 \%$ to $9.1 \%$ in PBST, depending on the amount of serum available. Incubation was for 1 hour at $23^{\circ} \mathrm{C}$.

2. Added rabbit-antj-catfish serum ( $5 \%$ solution, $0.1 \mathrm{~mL}$ ) to each well. Incubation was for 1 hour at $23^{\circ} \mathrm{C}$.

3. Added goat*-anti-rabbit solution (1:1000 dilution, $0.1 \mathrm{~mL}$ ) to each well. Incubation was for 1 hour at $23^{\circ} \mathrm{C}$.

4. Added 0.2-mL enzyme substrate to each we11. Plate $A$ incubated for 40 minutes at $23^{\circ} \mathrm{C}$; Plate $B$ incubated for 30 minutes at $23^{\circ} \mathrm{C}$.

The reaction was terminated by adding $0.05-\mathrm{mL} 3 \mathrm{~N} \mathrm{NaOH}$. Solutions from each pair of wells ( 1 and 2, 3 and 4, 5 and 6, etc.) were combined to be photospectroscopically analyzed with a Beckman DB-2.5 spectrophotometer.

Fourteen serum samples were analyzed (seven per plate). Fish from each experimental group were assigned to each plate. In all cases, wells 1 through 8 received diluted serum. Wells 9 through 12 were reserved for specific reagent control treatments.

\subsection{RESULTS}

\subsubsection{Screening ELISA}

The results of the screening ELISA expressed as absorbence at $405 \mathrm{~nm}$ for 25 minutes are presented below.

Fish No. 8 (sham vaccinated)
BSA WeI1
0.228
OA-BSA We11
0.102

Fish No. 16 (vaccinated with $50 \mu \mathrm{g}$ of OA-BSA)
BSA We1!
0.269
OA-BSA Wel1
0.820 
Control wells

$\begin{array}{ll}\text { Blocking agent } & 0.142 \\ \text { Less rabbit-anti-catfish } & 0.158\end{array}$

The screening assay was conducted on the assumption that a higher degree of activity associated with the OA-BSA-injected fish in wells coated with OA-BSA compared to wells coated with BSA only would indicate the presence of specific antibodies against ochratoxin-A. As was expected, there was no appreciable activity against either BSA or OA-BSA in the shamvaccinated fish. In contrast, there was about three times the activity against OA-BSA as observed against the carrier BSA. This contrast can be interpreted in one of two ways. The difference in reactivity can be attributed to the presence of antibodies against ochratoxin-A as a hapten. The other explanation is that the process of conjugating the ochratoxin to BSA altered the BSA such that its antigenic determinants were altered (i.e., denatured). Consequentiy, a different level of reactivity would be expected and could not necessarily be attributed to the hapten. I believe the second explanation is more likely because the activity associated with BSA was so close to the background levels while much higher levels of activity were observed with the OA-BSA in the screening assay. This hypothesis can be tested by treating BSA with the same conditions used to produce the conjugate described by Chu, Chang, and Hinsdill (1976) using 1-ethyl-3,3-dimethylamino-propyl-carbodi imide as a coupling agent. The treated BSA could be used as controls to detemine the effect of denaturing on the antigenic potential of the BSA component of the OA-BSA conjugate.

\subsubsection{Carboditimide BSA (BSA-CARB)}

\subsubsection{Control Treatments}

A minimum number of reagent control assays were conducted because of the limited amount of serum available for analysis. A series of control treatments were run in which the goat*-anti-rabbit reagent was not added. The absorbence at $405 \mathrm{~nm}$ for the controls on Plate B was 0.078 to 0.085 for wells precoated with OA-BSA and BSA-CARB (Table 1). These values were consistent for wells that received immune serum, control serum, and PBST. On Plate $A$, wells precoated with OA-BSA and BSA-CARB that received PBST 
TABLE 1. ELISA Control Treatments for OA-BSA Immunized Catfish

\begin{tabular}{|c|c|c|c|c|c|c|c|c|}
\hline Treatment & Plate & Serum & No. & $\begin{array}{r}\text { Reas } \\
\text { Rabbit- } \\
\text { anti- } \\
\text { catfish } \\
\end{array}$ & $\begin{array}{l}\text { Goats } \\
\text { anti- } \\
\text { rabbit }\end{array}$ & $\begin{array}{c}\text { We11 } \\
\text { (Absorbence } \\
\text { OA-BSA }\end{array}$ & $\begin{array}{l}\text { Treatment } \\
\text { value, } 405 \\
\text { BSA-CARB }\end{array}$ & $\mathrm{nm})$ \\
\hline Contro? & B & + & 5 & + & - & 0.085 & 0.081 & \\
\hline $100 \mu \mathrm{g}$ OA-BSA & $B$ & + & 11 & + & - & 0.083 & 0.079 & \\
\hline No serum & B & - & NA & + & - & 0.085 & 0.081 & \\
\hline No serum & B & - & NA & + & - & 0.080 & 0.082 & \\
\hline Control & A & + & 3 & - & + & 0.415 & 0.274 & \\
\hline $50 \mu \mathrm{g} O A-B S A$ & A & + & 14 & - & + & 0.613 & 0.379 & \\
\hline No serum & $A$ & - & NA & - & - & 0.115 & 0.116 & \\
\hline No serum & A & - & NA & - & - & 0.109 & 0.093 & \\
\hline
\end{tabular}

rather than a serum sample had an absorbence of 0.093 to 0.116 (these wells did not receive goat*anti-rabbit IgG). Although there was a slight difference between the plates, the amount of background activity in wells that did not receive goat*-anti-rabbit IgG was consistent. The higher values associated with PTate $A$ are indicative of the longer assay time of 40 minutes, compared to 30 minutes for Plate $B$. Background values in the absence of goat*anti-rabbit IgG are indicative of true background levels of substrate conversion in the assay.

There were two reagent controls on Plate $A$ where an immune serum sample (fish no. 14, injected with $50 \mu \mathrm{g}$ of OA-BSA) and a serum sample from a control fish (no injection) were loaded into wells 9 through 12 . In these treatments, rabbit-anti-catfish IgG was deleted, and goat*-antirabbit IgG was added. For both samples, the associated absorbence was considerably higher then that observed in the goat*-anti-rabbit IgG controls discussed above (see Table 1). Also, the absorbence in wells that were precoated with OA-BSA was consistently higher than that for wells precoated with BSA-CARB. This observation indicates an affinity (crossreactivity) of the goat*-anti-rabbit IgG for the catfish serum, which had 
been added to the wells. The only reagent absent in this set of controls was the rabbit-anti-catfish IgG. The observation also suggests that there could be cross-reactivity between the blocking agent ( $1 \%$ gelatin) and the goat*-anti-rabbit IgG.

\subsubsection{Assay for OA-Specific Antibodies}

Four experimental trials were conducted on each serum sample. The trials included wells that were precoated with carbonate buffer only (i.e., background controls), BSA, OA-BSA, or BSA-CARB. The absorbence values have not been adjusted for the 0.080 to 0.116 background readings (Table 2).

The first observation is the occurrence of high absorbence values associated with the carbonate buffer control treatments. These treatments were essentially control treatments because BSA or OA-BSA had not been added to the wells that were precoated with carbonate buffer. The remaining wells received all the remaining assay reagents, including the gelatin blocking reagent. Levels of enzyme activities were expected to be low, on the order of 0.100 , compared to the levels observed in the controls deficient in the rabbit-anti-catfish IgG $(0.415$ to 0.613$)$. The high level of activity in the carbonate buffer controls can be best explained by crossreactivity with the blocking agent and the goat*-anti-rabbit reagent. The carbonate controls still represent the level of activity that should be subtracted from the treatments in wells that were precoated with BSA, OA-BSA, or BSA-CARB.

In the control and sham-injected treatments, the carbonate buffer control values are generally less than those for the OA-BSA and BSA-CARB treatments. This relationship for the serum from the OA-BSA-injected catfish is considerably weaker and in some cases reversed. With the exception of fish nos. 12 and 13, the differences between the four well pretreatment groups are insignificant; however, the values for the OA-BSA treatments appear to consistently exceed those for the BSA treatments (Table 3), irrespective of the experimental group of fish. The largest positive differences were observed in the control group of catfish serum samples. Consequently, no definitive conclusion can be drawn regarding the presence of OA-specific antibodies in immunized catfish. 
TABLE 2. Absorbence Values for Catfish Serum Samples Analyzed With ELISA for the Detection of OA-Specific Antibodies

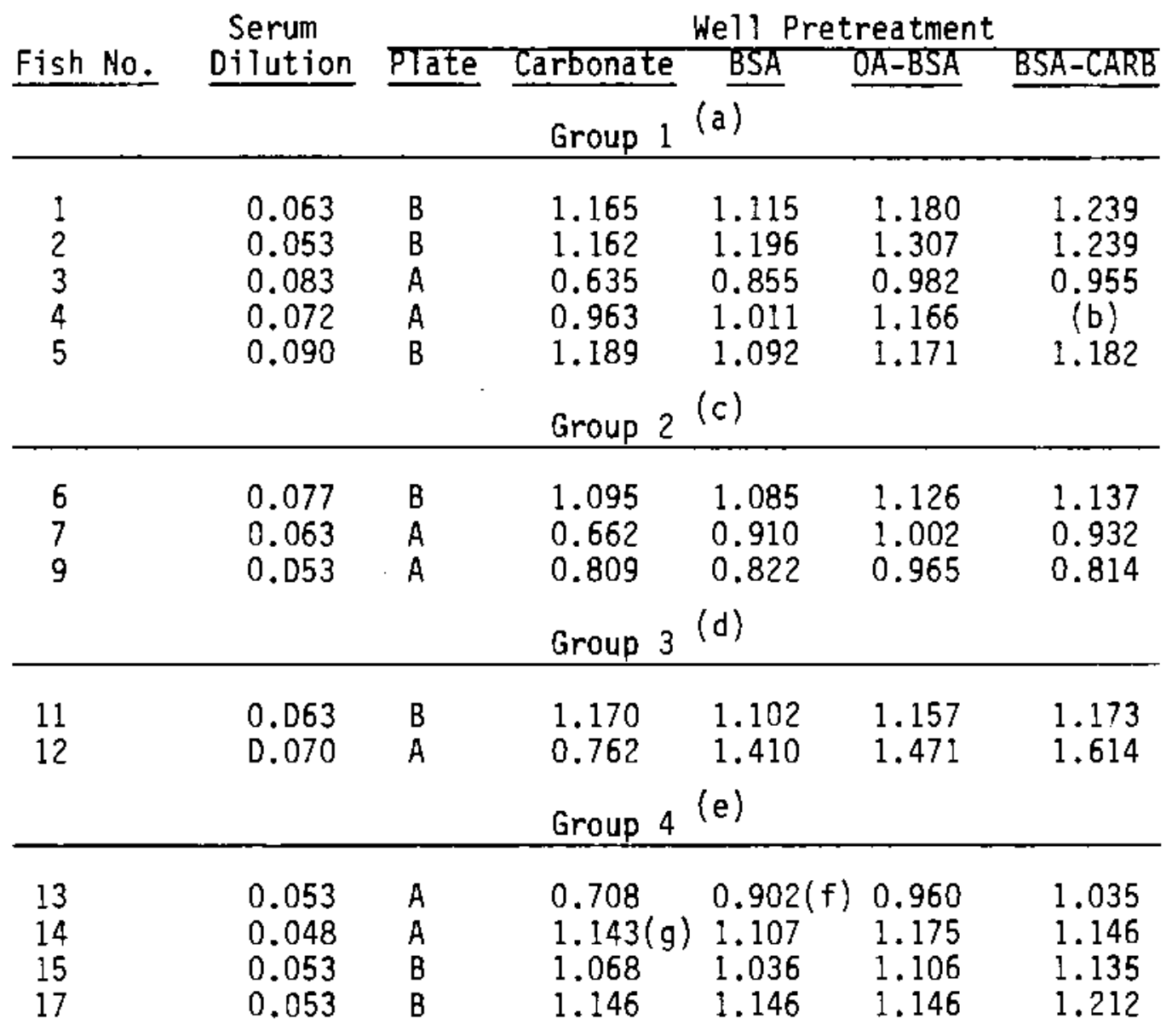

\footnotetext{
(a) Control group (serum from noninjected fish).

(b) Well No. G-7 developed a bubble during assay; value was invalid.

(c) Sham-injected group (serum from fish injected with $0.1-\mathrm{mL}$ FCA).

(d) Serum from fish injected with $100 \mu \mathrm{g}$ OA-BSA in 0.1-mL FCA.

(e) Serum from fish injected with $50 \mu \mathrm{g} O A-B S A$ in $0.1-m L$ FCA.

(f) Well No. C-3 received $0.1-\mathrm{mL} \mathrm{NaOH}$; absorbence was adjusted by $1.1 x$.

(g) Well No. D-1 appeared to have received on?y $0.1-\mathrm{mL}$ of enzyme substrate; absorbence value is suspected to be high due to dilution.
} 
TABLE 3. Difference in Absorbence Values for Catfish Serum Samples Analyzed With ELISA for Detection of OA-Specific Antibodies

\begin{tabular}{|c|c|c|c|c|}
\hline \multirow[t]{2}{*}{ Fish No. } & $\begin{array}{l}\text { Serum } \\
\text { Dilution }\end{array}$ & Plate & $\begin{array}{c}\text { OA-BSA Minus } \\
\text { BSA-CARB }\end{array}$ & \multirow[t]{2}{*}{$\begin{array}{l}\text { OA-BSA Minus } \\
\text { BSA }\end{array}$} \\
\hline & \multicolumn{3}{|c|}{ Group 1 (a) } & \\
\hline $\begin{array}{l}1 \\
2 \\
3 \\
4 \\
5\end{array}$ & $\begin{array}{l}0.063 \\
0.053 \\
0.083 \\
0.072 \\
0.090\end{array}$ & $\begin{array}{l}B \\
B \\
A \\
A \\
B\end{array}$ & $\begin{array}{c}0.011 \\
0.068 \\
0.027 \\
\langle\mathrm{~b}) \\
-0.011\end{array}$ & $\begin{array}{l}0.065 \\
0.111 \\
0.127 \\
0.155 \\
0.079\end{array}$ \\
\hline
\end{tabular}

\begin{tabular}{|c|c|c|c|c|}
\hline $\begin{array}{l}6 \\
7 \\
9\end{array}$ & $\begin{array}{l}0.077 \\
0.063 \\
0.053\end{array}$ & $\begin{array}{l}B \\
A \\
A\end{array}$ & $\begin{array}{r}-0.011 \\
0.070 \\
0.151\end{array}$ & $\begin{array}{l}0.041 \\
0.092 \\
0.143\end{array}$ \\
\hline \multicolumn{5}{|c|}{ Group $3^{(d)}$} \\
\hline $\begin{array}{l}11 \\
12\end{array}$ & $\begin{array}{l}0.063 \\
0.070\end{array}$ & $\begin{array}{l}\text { B } \\
\text { A }\end{array}$ & $\begin{array}{l}-0.016 \\
-0.143\end{array}$ & $\begin{array}{l}0.055 \\
0.061\end{array}$ \\
\hline \multicolumn{5}{|c|}{ Group 4 (e) } \\
\hline $\begin{array}{l}13 \\
14 \\
15 \\
17\end{array}$ & $\begin{array}{l}0.053 \\
0.048 \\
0.053 \\
0.053\end{array}$ & $\begin{array}{l}\text { A } \\
\text { A } \\
B \\
B\end{array}$ & $\begin{array}{r}-0.075 \\
0.029 \\
-0.029 \\
-0.066\end{array}$ & $\begin{array}{l}0.058 \\
0.068 \\
0.070 \\
0.000\end{array}$ \\
\hline
\end{tabular}

(a) Control group (serum from noninjected fish).

(b) Error in assay; value cannot be determined.

(c) Sham-injected group (serum from fish injected with $0.1-m \mathrm{~L}$ F(A).

(d) Serum from fish injected with $100 \mu \mathrm{g}$ OA-BSA in 0.1-mL FCA.

(e) Serum from fish injected with $50 \mu \mathrm{g}$ OA-BSA in 0.1-mL FCA. 


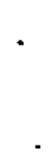




\section{D INDUCTION OF ANTIBODIES AGAINST T2 TOXIN}

A series of assays were conducted to determine if channel catfish vaccinated with $T 2$ toxin conjugated to $B S A$ would produce antibodies with specificity for the haptenized mycotoxin. The experiment involved the vaccination of two groups of channel catfish. Nine fish were vaccinated two times with T2-BSA in FCA (the two vaccinations were given 28 days apart). A control group was vaccinated with BSA in FCA on the same schedule. Blood serum samples were collected 60 days following the initial vaccination. ELISA were conducted with $T 2$ conjugated to keyhole limpet hemocyanin (KLH) and BSA.

\subsection{METHODS}

\subsubsection{Catfish Vaccination and Preparation of Vaccine}

Channel catfish were purchased from the Chico Game Fish Farm on April 2, 1986. The fish were initially placed in ambient well water and held at $17^{\circ} \mathrm{C}$ for 10 days. The catfish were acclimated to a temperature of $24^{\circ} \mathrm{C} \pm 1{ }^{\circ} \mathrm{C}$ over an 8 -day period at temperature increases of $1.0^{\circ} \mathrm{C}$ per day. The fish were acclimated to $24^{\circ} \mathrm{C} \pm 1{ }^{\circ} \mathrm{C}$ two weeks prior to vaccination and held at this temperature for the duration of the experiment.

It was difficult to dissolve the T2-BSA in distilled water. The solution required multiple disruptions with a Branson J17a ultrasonic disruptor. This treatment provided a fine suspension of particulate T2-BSA. A colorometric protein analysis indicated that there was very little of the conjugant in true solution. Nominal protein concentration after dialysis and sonication was estimated to be $0.75 \mathrm{mg} / \mathrm{mL}$.

The problem with dissolving the T2-8SA in distilled water was discussed with a technical representative of Sigma Chemical Company, who indicated that the specification sheet for the compound indicated that when $5 \mathrm{mg}$ are dissolved into $5 \mathrm{~mL}$, the resulting solution appears slightly cloudy. No other information was available on solubility of T2-BSA. The suspension that was used to inject the catfish should be more immunogenic; however, a dissolve solution is necessary for the ELISA assays. The Sigma 
representative suggested that DMSO might work as a solvent to get the material into solution.

The T2-BSA suspension solution (about $0.75 \mathrm{mg} / \mathrm{mL}$ ) was mixed $1: 1$ with FCA. The control treatment consisted of mixing a solution of BSA $(75 \mathrm{mg} / \mathrm{mL}$ in $1.7 \%$ saline) and $F C A$ at a ratio of $1: 1$. Fresh vaccine was similarly prepared for the second vaccination 28 days after the initial vaccination, and $219 \pm 15 \mu \mathrm{L}$ were injected into nine catfish. A control group of nine fish were also injected with BSA in FCA $(193 \pm 35 \mu \mathrm{L})$ to produce catfish anti-BSA serum.

\subsubsection{Sampling of Catfish Serum}

The catfish used for the experiments were anesthetized, weighed, and measured (standard length) at each vaccination and when serum samples were collected (Table 4). A syringe was used to collect blood from the caudal vein of each fish. The volume of solution injected during the first vaccination was $219 \pm 19 \mu \mathrm{L} \mathrm{T2-BSA}$ and $193 \pm 35 \mu \mathrm{L}$ BSA. The volume of solution injected in the second vaccination was $200 \mu \mathrm{L}$. When vaccinated, the experimental fish were weighed and measured (Table 4). Individual fish were identified by cold-branding.

Blood was allowed to clot for a period of not less than 1 hour after collection and was centrifuged in a Beckman Microfuge. Serum samples were stored at $-80^{\circ} \mathrm{C}$ pending analysis for T2-specific antibodies.

A separate group of four rainbow trout were also injected twice with BSA. Blood from the trout was sampled on July 1, 1986. The trout-anti-BSA sera may be used and compared to goat-anti-BSA IgG (Sigma Chemical Co.) as a blocking agent for BSA-antigenic sites on the T2-BSA reagent used in ELISA.

\subsubsection{Enzyme-Linked Immuno Sorbant Assay}

Several screening tests were performed to evaluate cross reactivity of the rabbit-anti-catfish IgG with the reagents used to conduct ELISA. Because the T2-BSA obtained from the Sigma Chemica? Company would not completely dissolve in distilled water, alternative methods were developed for precoating the Immulon-2 plates for ELISA. ELISA plates were read with a Bio-Tek Instruments Model EL 309 Microplate Autoreader. 
TABLE 4. Combined Growth of Experimental Fish, T?-BSA-Vaccinated Fish and BSA-Vaccinated Fish $(N=18)$

\begin{tabular}{lccccc} 
Date & Treatment & Mean Weight (g) & S.D. & & Range (g) \\
\hline $5 / 02 / 86$ & 1st Injection & 49.69 & 7.18 & $37-61$ \\
$5 / 30 / 86$ & 2nd Injection & 73.69 & 9.09 & $62-92.5$ \\
$7 / 01 / 86$ & 1st Bleeding & 93.97 & 13.88 & $80-120.5$
\end{tabular}

\section{1 .3 .1 Screening ELISA}

Screening assays with several dilutions of catfish sera were conducted with numerous reagent control treatments. Test 1 was performed to determine the working range of each fish serum and cross reactivity with reagents.

Test 2 was performed to determine the reactivity of goat*anti-rabbit IgG at concentrations of 100,200 and $400 \mathrm{ng} / \mathrm{mL}$ and the optimum assay duration $(30,60$, or 90 minutes $)$. At $200 \mathrm{ng} / \mathrm{mL}$ of the reagent per we 11 , the absorbence $\left(405 \mathrm{~nm}\right.$ ) should be 1.000 at 30 minutes (incubation at $37^{\circ} \mathrm{C}$ ). During this test, gelatin (1\%) was used in the wells to block unoccupied binding sites (>24-hour treatment).

Test 3 was conducted without using the gelatin blocking agent. Treatments included 1) four concentrations of rabbit-IgG, 2) four concentrations of BSA, 3) three concentrations of catfish anti-BSA sera, and 4) one controi containing $10 \%$ rabbit-anti-catfish IgG. The catfish anti-8SA was tested to determine if the rabbit-anti-catfish IgG obtained from $\mathrm{Dr}$. Lobb last year retained its specificity. (Immunodiffusion tests conducted in 1986 indicated that it retained its activity up to that point.) Assays were conducted for 30 minutes at $24^{\circ} \mathrm{C} \pm 2^{\circ} \mathrm{C}$.

Test 4 was performed with 10\% immune catfish serum, $10 \%$ immune trout serum (both against BSA), goat-anti-BSA IgG, $200 \mathrm{ng} / \mathrm{mL}$ BSA and background absorbence $(405 \mathrm{~nm})$ determinations of $200 \mathrm{ng} / \mathrm{mL}$ BSA, followed by additions of goat-anti-BSA or immune trout serum (against BSA) for 3 hours. The 
objective of these assays was to evaluate cross reactivity of goat*-antirabbit IgG with any of the remaining components that will be used to test the immune catfish sera for T2-specific antibodies. Assays were conducted for 30 minutes at $24^{\circ} \mathrm{C} \pm 1^{\circ} \mathrm{C}$.

\subsubsection{ELISA for T2-Specific Antibodies}

Two methods were used to determine the presence of T2-specific antibodies in channel catfish serum. The initial method involved cross-linking the T2 toxin with KLH in Immulon-2 plate wells. The second method followed the first, only BSA replaced KLH as a cross-linking protein. The second technique consisted of the following steps:

1. added $0.62 \mathrm{~mL}$ of $1.25-\mathrm{mg} \mathrm{KLH} / \mathrm{mL}$ to $52 \mathrm{~mL}$ of $0.1-\mathrm{M}$ sodium acetate buffer ( $\mathrm{pH}$ 4.2)

2. added $0.078 \mathrm{~mL}$ of $5-\mathrm{mg} \mathrm{T} 2 / \mathrm{mL}$ of $75 \%$ methanol to 1 (above)

3. added $9.14 \mathrm{~mL}$ of forma 1 in to 1 (above).

The cross-linking solution was then pipetted in $0.2-\mathrm{mL}$ increments into selected wells of Immulon-2 plates. The same procedure was used for the control treatment except that $75 \%$ ethanol was used in place of the $\mathrm{T} 2$ in $75 \%$ methanol solution. Each Immulon-2 plate contained an equal number of wells receiving cross-1 inked $12-\mathrm{KLH}$ and $\mathrm{KLH}$. Plates were allowed to incubate at room temperature for at least 3 days prior to processing. Plate wells were rinsed five times with PBST prior to adding any ELISA reagents.

The same methods were used to prepare cross-linked T2 BSA and BSA in Immulon-2 plates. The concentration of BSA used was $0.39 \mathrm{~mL}$ of $2.0 \mathrm{mg}$ $\mathrm{BSA} / \mathrm{mL}$.

\subsubsection{Keyhole Limpet Hemocyanin}

Two separate assays were conducted with T2-KLH precoated plates. The initial test was a screening test using four catfish serum samples. Two serum samples were taken from fish immunized with T2-BSA and two from fish inmunized with BSA. The dilution of the catfish serum was $10 \%$; incubation was for 1 hour at $23^{\circ} \mathrm{C}$. A blocking agent ( $1 \%$ gelatin) was not used in this assay. A higher relative absorbence in wells precoated with T2-KLH than in 
wells precoated with KLH would indicate specific activity against the haptenized mycotoxin.

A second ELISA was performed with the addition of the blocking agent ( $1 \%$ gelatin); however, the treatment duration was reduced from 24 hours to 1 hour. This assay was conducted to determine if the blocking agent would reduce the high level of nonspecific reactivity observed in the first T2-KLH assay. One serum sample from a catfish immunized with T2-BSA (fish No. 17) was used in this test. Serum was diluted to $5 \%$ in PBST.

\subsubsection{Bovine Serum Albumin}

A screening test and a definitive test were performed using Immulon-2 plates precoated with cross-linked T2-BSA and BSA.

A screening test was performed to determine the baseline level of activity with Immulon-2 plates precoated with cross-linked T2-BSA and BSA. Gelatin (1\%) was used as a blocking agent for 1 hour. Two serum samples from a T2-BSA-immunized fish (No. 11) and a BSA-immunized fish (No. 15) were assayed at $5 \%$ dilution in PBST. A $2 \%$ solution $(v / v)$ of rabbit-anticatfish IgG was used as the second antibody.

A definitive assay was completed using three Immulon-2 plates. Two plates were used for the assay of serum samples in triplicate. The third plate was used to determine background activity (no serum added). The concentration of serum was $5 \%(\mathrm{v} / \mathrm{v})$. Gelatin $(1 \% \mathrm{v} / \mathrm{v})$ was used as a blocking agent for 1 hour at $23^{\circ} \mathrm{C}$. The enzyme reaction ran for 30 minutes at $23^{\circ} \mathrm{C}$. Three groups of catfish sera were assayed: T2-BSA immunized ( $N=$ 9), BSA immunized $(N=9)$, and a nonimmunized reference group $(N=2)$.

\subsection{RESULTS}

\subsubsection{Screening Elisa}

The absorbence (405 nm) values for $5 \%$ and $1.25 \%$ catfish sera were 0.173 and 0.155 , respectively. Nonspecific binding was observed in control wells that received the enzyme labelled goat*-anti-rabbit IgG but did not receive catfish sera. These results suggest binding to either the gelatin or unblocked-binding sites on the Immulon-2 plates. 
Test 2 failed because all sites that received the gelatin read off scale on the plate counter. The failure was apparent early in the test and the last sample was taken at 70 minutes rather than 90 minutes. However, control treatments that did not receive gelatin had absorbence (405 $\mathrm{nm}$ ) values of 0.061 to 0.214 over the $30-, 60$ - and 70 -minute incubation period at about $25^{\circ} \mathrm{C}$. Control wells that received gelatin read 1.516 at 30 minutes and off scale at 60 minutes. These results indicated that the gelatin greatly elevated background absorbence when the blocking agent was added for $>24$ hours. The results also suggested that the goat*-anti-rabbit IgG retained high enzymatic activity.

Test 3 indicated that the activity of the goat*-anti-rabbit IgG was close to the expected activity of 1.000 absorbence units $(405 \mathrm{~nm})$ for 30 minutes at $37^{\circ} \mathrm{C}$ and that the reagent had retained acceptable activity. The addition of rabbit-anti-catfish IgG indicated background levels of 0.070 that will have to be subtracted from absorbence values used in the assays for T2-specific antibodies. Test wells that received dilutions of immune catfish sera (anti-BSA) indicated that the catfish sera can be diluted to $10 \%$ without a significant reduction in absorbence under the assay conditions. I am uncertain at this time as to why there was not a positive increase of absorbence with increasing concentration of serum. Cross reactivity of the goat*-anti-rabbit IgG with BSA was negligible.

The test 4 series confirmed that there was a negligible amount of background activity associated with BSA (Table 5), goat*-anti-BSA IgG up to $4.425 \mu \mathrm{g} / \mathrm{mL}$, and trout-anti-BSA (Table 6). The catfish serum sample was taken from a different fish that was immunized with BSA, thus the difference in absorbence $(405 \mathrm{~nm})$ between this sample and the sample in Table 5 may simply indicate the normal range of variability.

\subsubsection{ELISA for T2-Specific Antibodies}

\subsubsection{Keyhole Limpet Hemocyanin}

The activity (absorbence) on the plates used for this test was expected to be relatively low because cross reactivity between BSA-specific antibodies and KLH epitopes was expected to be small. However, relatively 
TABLE 5. Absorbence Values From ELISA of Rabbit IgG, BSA, Catfish-anti-BSA, and Rabbit-anti-catfish IgG

\begin{tabular}{|c|c|c|}
\hline Treatment & $\begin{array}{l}\text { Concentration } \\
\text { (ng/mL or } \%) \\
\end{array}$ & $\begin{array}{c}\text { Mean absorbence }(405 \mathrm{~nm}) \\
( \pm 1.0 \mathrm{~S} .0 .) \\
\end{array}$ \\
\hline $\begin{array}{l}\text { Blank } \\
\text { Control-1 }\end{array}$ & $\begin{array}{c}0 \\
10 \%\end{array}$ & $\begin{array}{l}0.000(0.006)(\mathrm{a}) \\
0.070(0.010)\end{array}$ \\
\hline Rabbit-IgG & $\begin{array}{r}10 \\
50 \\
100 \\
200\end{array}$ & $\begin{array}{l}0.030(0.008) \\
0.367(0.028) \\
0.663(0.063) \\
1.109(0.060)\end{array}$ \\
\hline BSA & $\begin{array}{r}10 \\
50 \\
100 \\
200\end{array}$ & $\begin{array}{l}-0.003(0.008) \\
-0.012(0.001) \\
-0.012(0.013) \\
-0.012(0.001)\end{array}$ \\
\hline $\begin{array}{l}\text { Catfish } \\
\text { serum }\end{array}$ & $\begin{array}{l}50 \% \\
20 \% \\
10 \%\end{array}$ & $\begin{array}{l}1.030(-\ldots-) \\
1.142(----) \\
1.088(-\ldots-)\end{array}$ \\
\hline
\end{tabular}

(a) Blank values subtracted from all other values before calculating mean values.

(b) Ten percent rabbit-anti-catfish IgG serum in PBST added to wells that had not received any prior coating.

high absorbence levels were observed in the wells receiving $10 \%$ catfish serum (Table 7). Control treatments in wells that were not precoated with T2-KLH or KLH, but received $10 \%$ serum, had absorbence values ranging from 0.463 to 0.708 . These values, which generally exceeded those for levels in the precoated wells, indicate that the T2-KLH and KLH bound to the Immulon-2 plates. However, the degree of binding is uncertain. Plate wells that did not receive catfish serum but were coated with T2-KLH and $\mathrm{KL} H$ and received rabbit-anti-catfish IgG had absorbence values ranging from 0.168 to 0.193 and 0.169 to 0.206 , respectively. These values exceed those for background wells (no T2-KLH or KLH, inmune catfish serum, or rabbitanti-catfish IgG) by a factor of two. Collectively, the results of this assay indicate a potential for high nonspecific binding of immune catfish 
TABLE 6. ELISA for Other Reagents to be Used in Assays for T2-Specific Antibodies in Immune Catfish Serum (values corrected for background levels)

\begin{tabular}{|c|c|c|}
\hline Treatment & $\begin{array}{l}\text { Concentration } \\
\text { (ng/mL or } \%) \\
\end{array}$ & $\begin{array}{l}\text { Mean absorbence }(405 \mathrm{~nm}) \\
( \pm 1.0 \mathrm{~S} .0 .)\end{array}$ \\
\hline BIank & 0 & $0.000(0.015)$ \\
\hline $\begin{array}{l}\text { Catfish- } \\
\text { anti-BSA }\end{array}$ & $10 \%$ & $0.449(0.045)$ \\
\hline $\begin{array}{l}\text { Trout- } \\
\text { anti-BSA }\end{array}$ & $10 \%$ & $0.065(0.032)$ \\
\hline BSA & 200 & $-0.006(0.008)$ \\
\hline $\begin{array}{l}\text { BSA + goat- } \\
\text { anti-BSA }\end{array}$ & $\begin{array}{c}0^{(\mathrm{a})} \\
44 \\
443 \\
4425 \\
44,250\end{array}$ & $\begin{array}{l}0.006(0.008) \\
0.019(0.021) \\
0.008(0.01 .6) \\
0.014(0.027) \\
0.028(0.014)\end{array}$ \\
\hline $\begin{array}{l}\text { BSA + trout- } \\
\text { ant } i-B S A\end{array}$ & $\begin{array}{c}0 \% \\
0 \% \\
5 \% \\
10 \% \\
20 \% \\
50 \%\end{array}$ & $\begin{array}{r}0.003(0.006) \\
0.019(0.013) \\
-0.005(0.000) \\
-0.010(0.002) \\
-0.011(0.006)\end{array}$ \\
\hline
\end{tabular}

(a) Goat-anti-RSA added to wells coated with $200 \mathrm{ng} / \mathrm{mL}$ RSA.

(b) Trout-anti-BSA serum added to wells coated with $200 \mathrm{ng} / \mathrm{mL}$ BSA.

serum to wells precoated with T2-KLH and KLH. The presence of unblocked binding sites on the plates was indicated by the fact that wells receiving immune catfish serum without any precoating of $\mathrm{KLH}$ had absorbence values exceeding levels of wells that were precoated. The high backaround activity may be reduced by adding gelatin; however, the incubation length should be reduced to minimize nonspecific binding, as was observed in previous trials with ELISA.

The first test did not indicate the presence of specific antibodies aqainst T?. Levels of activity associated with KLH exceeded levels associated with T2-KLH precoated plates for the two catfish immunized with T2-BSA and in one of the two fish immunized with BSA. Although the higher 
TABLE 7. Initial ELISA of Four Catfish Sera on Plates Precoated with T2-KLH and KLH (absorbence values at $405 \mathrm{~nm}$; background not subtracted)

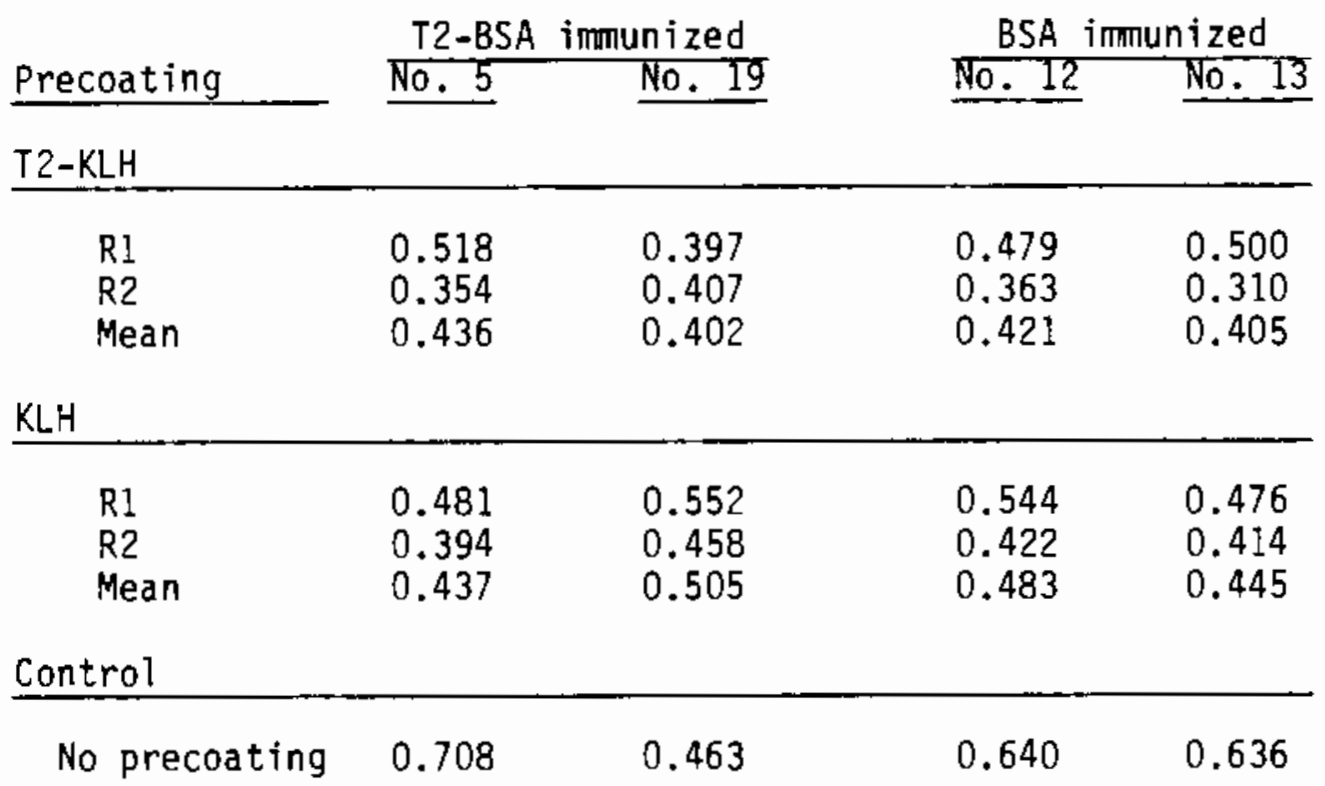

activity levels may indicate a lack of antibodies against $T 2$ toxin, it is possible that the level of T2-specific antibodies is small, and the high cross-reactivity observed in the test wells may be masking the presence of T2-specific antibodies.

A second assay was conducted using $1 \%$ gelatin applied for 1 hour as a blocking agent, with a $5 \%$ serum sample obtained from a fish immunized against T2-BSA (No. 17) (Table 8). Wells were also tested that did not receive the $1 \%$ gelatin blocking agent. Adding the $1 \%$ gelatin for 1 hour reduced the background absorbence by $20 \%$ to $25 \%$ in wells that received $5 \%$ serum. A greater decrease in background absorbence was observed in controt wells that did not receive immune catfish serum. As noted in the initial trial with $\mathrm{KLH}$-precoated wells, the results for serum sample No. 17 did not indicate the presence of specific antibodies to the T2 hapten. The blocking agent appears to be blocking available binding sites in the wells. The difference in this trial with the $1 \%$ gelatin is that the wells were incubated at room temperature and not over extended periods (>24 h), as was done with ELISAs conducted previous?y for ochratoxin and T2. 
TABLE 8. Effect of Gelatin Blocking Agent on ELISA of Immune Catfish Serum in Wells Precoated With T2-KLH and KLH

\begin{tabular}{|c|c|c|c|c|c|}
\hline Trea tment & $\begin{array}{r}\text { Serum } \\
(5 \%)\end{array}$ & $\begin{array}{c}\text { Gelatin } \\
(1 \%)\end{array}$ & $\underline{N}$ & $\begin{array}{l}\text { Absorbence } \\
\text { Mean (S.D.) }\end{array}$ & $\frac{405 \mathrm{~nm})}{\text { Range }}$ \\
\hline $\begin{array}{l}\text { T2-KLH } \\
\text { T2-KLH }\end{array}$ & + & $\begin{array}{l}+ \\
-\end{array}$ & $\begin{array}{l}4 \\
4\end{array}$ & $\begin{array}{l}0.405(0.013) \\
0.505(0.037)\end{array}$ & $\begin{array}{l}0.393-0.423 \\
0.474-0.558\end{array}$ \\
\hline $\begin{array}{l}\mathrm{KLH} \\
\mathrm{KLH}\end{array}$ & $\begin{array}{l}+ \\
+\end{array}$ & $\begin{array}{l}+ \\
-\end{array}$ & $\begin{array}{l}4 \\
4\end{array}$ & $\begin{array}{l}0.399(0.028) \\
0.522(0.038)\end{array}$ & $\begin{array}{l}0.371-0.433 \\
0.484-0.567\end{array}$ \\
\hline $\begin{array}{l}\text { T2-KLH } \\
\text { T2-KLH }\end{array}$ & - & $\begin{array}{l}+ \\
-\end{array}$ & $\begin{array}{l}2 \\
2\end{array}$ & $\begin{array}{l}0.167(-\cdots) \\
0.310(-\cdots)\end{array}$ & $\begin{array}{l}0.139-0.194 \\
0.286-0.333\end{array}$ \\
\hline
\end{tabular}

The initial screening assay indicated that the plates had high levels of T2-BSA and BSA binding during precoating. The absorbence values for fish No. 11 (T2-BSA immunized) were 1.441 and 1.503 in wells precoated with T2-8SA, and 1.419 and 1.470 in wells precoated with BSA. Absorbence values for fish No. 15 (BSA immunized) were 1.707 and 1.698 for wells precoated with T2-BSA and 1.711 and 1.722 for wells precoated with BSA. Background absorbence ranged from 0.146 to 0.158 in wells that did not receive immune serum. It was concluded that the plates precoated with cross-linked T2-BSA and BSA were suitable for assaying the remaining serum samples.

The definitive assays failed to demonstrate any significant level of absorbence that could be attributed to T2-specific antibodies. Mean background absorbence from non-precoated wells receiving immune serum was subtracted from each well reading before the three values were added to produce a mean level of activity for that treatment. On this basis, control fish that did not receive immunization had mean absorbence values of about 0.402 and 0.455 , irrespective of whether the samples were read from wells precoated with T2-BSA or BSA (Table 9). These values indicated the range of normal background activity in nonimmunized catfish serum. Levels of absorbence in serum samples from T2-BSA-immunized fish were only slightly higher than those for the control fish. The BSA-immunized fish had significantly higher absorbence values than the T2-BSA-immunized fish. 
TABLE 9. ELISA of Catfish Immunized Against T2-BSA and BSA (absorbence corrected for background)

\begin{tabular}{|c|c|c|c|}
\hline \multirow[t]{2}{*}{ Fish No. } & $\begin{array}{l}\text { Mean Absorbence } \\
\text { T2-BSA-precoated } \\
\text { We } 11 \mathrm{~s}\end{array}$ & $\begin{array}{l}05 \mathrm{~nm})( \pm \text { S.D. }) \\
\text { BSA-precoated } \\
\text { Wells } \\
\end{array}$ & \multirow[t]{2}{*}{ Difference } \\
\hline & \multicolumn{2}{|c|}{ T2-BSA-immunized } & \\
\hline $\begin{array}{l}3 \\
4 \\
8 \\
10 \\
11 \\
12 \\
13 \\
16 \\
17\end{array}$ & $\begin{array}{l}0.517(0.023) \\
0.519(0.013) \\
0.587(0.007) \\
0.508(0.009) \\
0.584(0.035) \\
0.613(0.040) \\
0.418(0.018) \\
0.643(0.005) \\
0.612(0.020)\end{array}$ & $\begin{array}{l}0.512(0.067) \\
0.563(0.027) \\
0.601(0.022) \\
0.564(0.040) \\
0.599(0.045) \\
0.583(0.027) \\
0.450(0.004) \\
0.667(0.035) \\
0.606(0.044)\end{array}$ & $\begin{array}{r}0.005 \\
-0.044 \\
-0.014 \\
-0.056 \\
-0.015 \\
0.030 \\
-0.032 \\
-0.024 \\
0.006\end{array}$ \\
\hline \multicolumn{4}{|c|}{ BSA-immunized } \\
\hline $\begin{array}{r}5 \\
6 \\
7 \\
9 \\
14 \\
15 \\
18 \\
19 \\
20\end{array}$ & $\begin{array}{l}0.743(0.065) \\
0.773(0.033) \\
0.678(0.041) \\
0.807(0.018) \\
0.688(0.069) \\
0.702(0.028) \\
0.629(0.033) \\
0.746(0.038) \\
0.682(0.060)\end{array}$ & $\begin{array}{l}0.785(0.052) \\
0.743(0.053) \\
0.704(0.035) \\
0.764(0.034) \\
0.710(0.020) \\
0.726(0.024) \\
0.615(0.018) \\
0.714(0.024) \\
0.659(0.054)\end{array}$ & $\begin{array}{r}-0.042 \\
0.030 \\
-0.026 \\
0.043 \\
-0.022 \\
-0.024 \\
0.014 \\
0.032 \\
0.023\end{array}$ \\
\hline \multicolumn{4}{|c|}{ Nonimmunized Control } \\
\hline$\frac{1}{2}$ & $\begin{array}{l}0.457(0.033) \\
0.392(0.013)\end{array}$ & $\begin{array}{l}0.454(0.067) \\
0.413(0.017)\end{array}$ & $\begin{array}{r}0.003 \\
-0.021\end{array}$ \\
\hline
\end{tabular}

Fish immunized with T2-BSA did not have absorbence values on T2-BSA precoated wells greater than the values in their corresponding wells precoated with BSA. These results indicate that if specific antibodies were produced against the $T 2$ hapten, they were not produced in measurable quantities by the methods used in this assay. An alternative explanation is that the immunized catfish failed to recognized the $T 2$ hapten as an antigenic epitope, and no antibodies were produced. 


\subsection{MYELOMA INDUCTION}

Several methods were used to induce the formation of myelomas in catfish, including long-term exposure of catfish to a nontoxic concentration of benzene in water, exposure to pristane and benzene, and the in vitro exposure of catfish spleenocytes and kidney cells to $x$-ray irradiation. The exposure systems were designed to produce a myelogenous cell line that ultimately would be used for fusions with antibody-producing lymphocytes to produce a hybridoma cell line that produces monoclonal antibodies against mycotoxins.

\subsection{METHODS}

\subsubsection{Channel Catfish}

The channel catfish used in these studies were purchased from Bob Fattig (Brady, NB) in August 1984. These fish were used for the studies with ochratoxin, in vivo myeloma studies with benzene and pristane, and in vitro experiments with benzene. Catfish obtained from the Chico Game Fish Farm (Chico, CA) were used as a source of cells for the $x$-ray exposure.

\subsubsection{Sampling and Culture of SpTeen and Kidney Celis}

Xidney and spleen tissue was aseptically removed from catfish and transferred to sterile culture media. Cell suspensions were prepared by mechanically mincing the tissue with microdissecting sissors, forceps, and dissecting needles. In some cases, cell suspensions were cleaned by centrifugation and resuspension of cells in fresh media. In other cases, crude suspensions were cultured. Because of the relatively smali size of the catfish (about 10 to $20 \mathrm{~g}$ ), limited amounts of cells were available for cuiture.

Cells from the kidney and spleen of the catfish were cultured in Leibovitz's (L-15) medium with $10 \%$ heat inactivated fetal bovine serum (FBS). The broad spectrum antibiotic gentimycin was added to inhibit fungal and bacterial contamination. Cell cultures were conducted at $20^{\circ} \mathrm{C}$ in glass humidity chambers to prevent evaporation. 


\subsubsection{Benzene Exposures}

According to epidemiological data, benzene is an established human carcinogen for leukemia. Therefore, benzene was selected as a chemical agent to induce myelomas in catfish. Exposure methods included exposure of juvenile catfish to benzene in water, intraperitoneal (ip) injection of benzene in pristane, and in vitro exposure of catfish sleenocytes and kidney cells.

\subsubsection{Waterborne Exposures}

Because of benzene's high volatility and its relatively low solubility in water $(0.82 \mathrm{~g} / \mathrm{L})$, a special dosing apparatus was designed. A waterbased stock solution of benzene was pumped into an inflow line of a $200-\mathrm{L}$ aquarium for exposures. The stock solution (440 $\mathrm{mg}$ benzene/L) was pumped from a reservoir that attached to an air saturation chamber containing benzene. All air that displaced the stock solution as it was metered into the exposure aquaria was saturated with benzene, thereby minimizing the loss of benzene from the stock solution. The saturation chamber consisted of a vessel containing benzene that was passively vented to ambient air. The exposure aquaria, metering system, and dilution apparatus were placed in a HEPA-filtered hood. The exposure level of benzene was about 100 to $200_{\mu} \mathrm{g}$ benzene/L. In July 1986, the channel catfish showed signs of stress and the exposure system was briefly modified to allow intermittent delivery of benzene for 3 days. After the fish recovered, exposures continued for the remainder of the study except for brief periods when the stock solution was changed or the benzene pumping system malfunctioned (i.e., air locks).

There is no simple established method for monitoring benzene in water except by extraction with organic solvents and subsequent gas chromatographic (GC) analysis. We have investigated the possibility of determining UV absorbence of benzene in water and found a distinctive chromatogram. Benzene mixed with water produces maximal absorbence at 210-213 nm and five smaller peaks in the range of 234 to $264 \mathrm{~nm}$. The use of acetone to facilitate benzene dissolution in water was investigated, but the acetone 
formed a large peak that obscured the peaks in the 234- to 264-nm range. There was an apparent trough in the area of maximum absorbence for benzene at $21 ? \mathrm{~nm}$, but the presence of acetone elevated the baseline in this region. Stock solutions of benzene were monitored by UV analysis to determine and document the reproducibility of stock solution preparation. The method could not detect levels of benzene in exposure water that contained about 100 to $200 \mu \mathrm{g}$ benzene/L of water.

\subsubsection{Preparation of Stock Solutions}

A 2-L aspirator bottle was used to develop a closed system for mixing benzene with water. A rubber serum vial cap was placed over the aspirator tubing outlet and the top of the aspirator bottle was stoppered with a rubber stopper after being filled to overflowing with distilled water. Syringes were inserted into the stopper and the aspirator tube. Benzene $(0.5 \mathrm{~mL})$ was injected into the bottle through the aspirator tube while displaced water was vented through a syringe inserted through the stopper. The volume of water in the bottle was determined gravimetrically. The bottle was placed overnight on a stirrer. There was no visible evidence of undissolved benzene after 24 hours of mixing. The concentration of dissolved benzene was assumed to be about $200 \mathrm{mg}$ benzene/ $\mathrm{L}$, about one fourth the reported solubility. Dilutions were prepared from this solution to develop a standard curve that appeared to be linear over the UV absorbence range of 0.000 to 0.300 at $212 \mathrm{~nm}$.

As the exposure progressed, the 2-L bottle was replaced with stock solutions prepared in either 4-L or 46-L Pyrex carboys. The larger stock solutions were replaced every 34 days. The chronic exposure was initiated on June 14, 1985, and was terminated on February 14, 1986.

\subsubsection{Exposure of Catfish}

Forty catfish were cold branded for identification and bled to determine baseline distribution of fish blood cells. A reference group of about 20 catfish were placed in a separate $200-\mathrm{L}$ aquarium. The fish were maintained on well water $\left(16^{\circ} \mathrm{C}-17^{\circ} \mathrm{C}\right)$ at about $1.0 \mathrm{~L} / \mathrm{min}$ of either pure we 11 water or benzene-dosed well water. After the initial month of exposure, 
nine catfish were randomly selected from the benzene-exposure group to receive injections of pristane. Four injections of $0.1-\mathrm{mL}$ pristane were given over a 4 month period. After the injections, the catfish were returned to the benzene-exposure system. The distribution of blood cells in these fish was monitored over 8 months. The sampling schedule is summarized below.

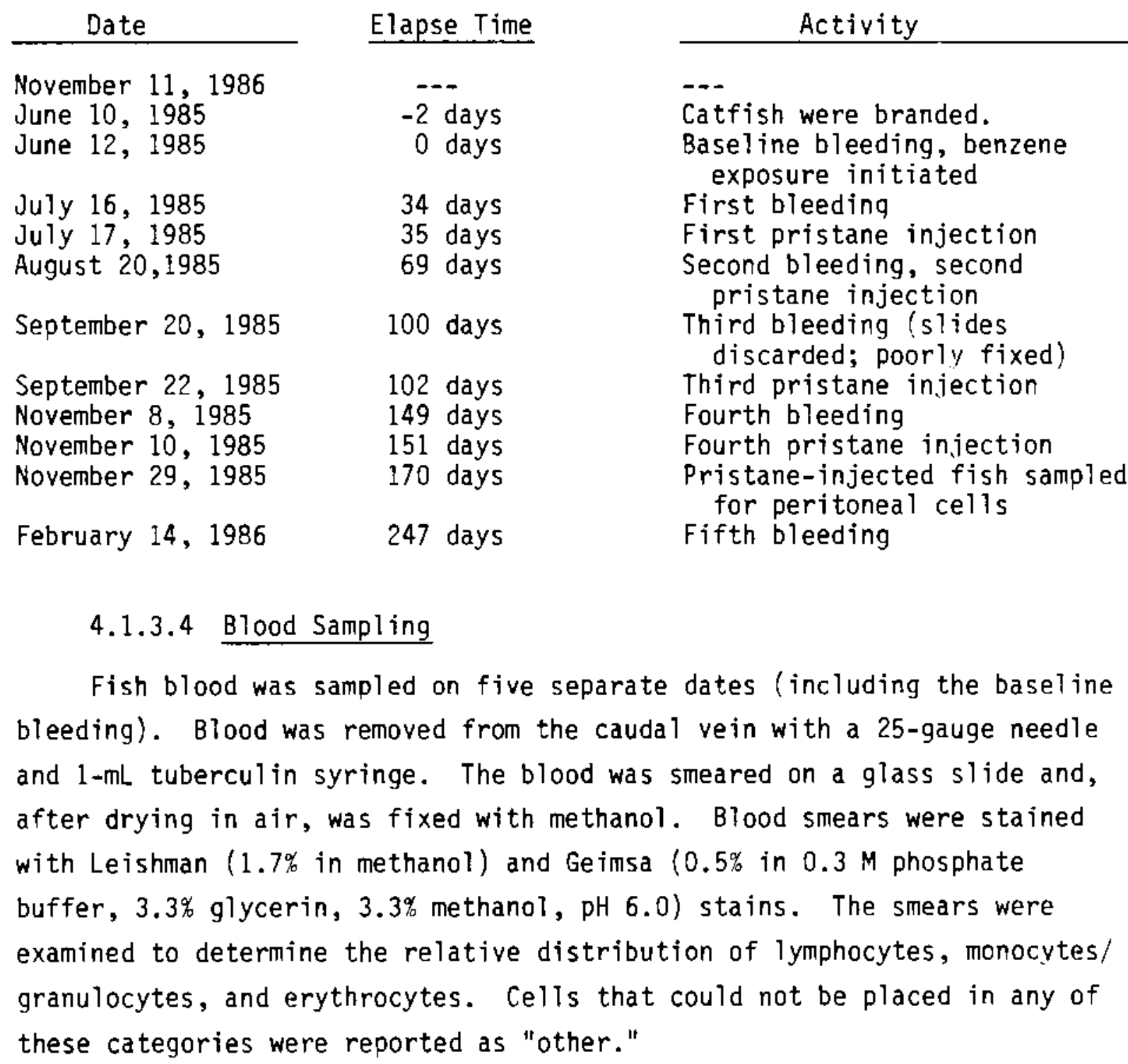




\subsubsection{Pristane Exposures}

Three experimental groups of catfish were treated with pristane to induce myeloma formation. These groups included Group $A$, which received four injections of $0.1-\mathrm{mL}$ pristane; Group $B$, which received $0.1-\mathrm{mL}$ of pristane containing 50- $\mu \mathrm{L}$ benzene; and Group $C$, which consisted of nine fish exposed to waterborne benzene that received four 0.1-mL injections of pristane. The last group (Group C) was also bled on the same schedule as the catfish in the benzene experiments. The catfish were maintained on ambient well water $\left(17^{\circ} \mathrm{C}\right)$ for the duration of the study.

Nine catfish in each treatment were injected $i . p$. four times over a 116-day period (schedule is summarized in Section 4.1.3.3). About 20 days after the fourth injection, the experimental catfish were sampled nondestructively for peritoneal cells by injecting into and removing from the body cavity $0.5 \mathrm{~mL}$ of saline.

Fish from treatment $A$ and $B$ were cold branded for individual identification prior to sampling. Group $C$ fish had been cold branded when the benzene exposures were initiated in June 1985. The three groups of catfish were sampled on November 26, 27, and 29, 1985 (groups A, B, and C, respectively).

The saline solutions were centrifuged at $4^{\circ} \mathrm{C}$ at $3000 \times \mathrm{g}$, and the cells resuspended in $0.2 \mathrm{~mL}$ of L-15 media amended to $10 \%$ FBS and $50 \mu \mathrm{g} / \mathrm{mL}$ gentimycin. A smal1 volume of saline was removed for quantification of cells using trypan blue exclusion and hemocytometry. Cells were cultured in 96-well tissue culture plates at $20^{\circ} \mathrm{C}$. STides were also prepared for each sample by mixing and smearing $10 \mu \mathrm{L}$ of saline wash with $10 \mu \mathrm{L}$ of FBS. Cells were air dried, fixed in methanot, and stained with Leishman and Giemsa stains.

\subsubsection{In vitro Exposures}

Catfish cells from the spleen and kidney were cultured and exposed in vitro to benzene and $x$-ray irradiation. The objective of these exposures was to transform normal catfish lymphocytes into immortal celis that could be used for subsequent fusions with immunocompetent antibody-producing 
cells. Transformed cells were expected to survive and dominate nontransformed cells in culture. All cell cultures died after about 10 to 14 days of culture. Additional work must be done to define culture requirements of fish Tymphocytes.

Cultures of spleen cells were exposed to $1.0-\mathrm{mM}$ benzene in media and cultured at $20^{\circ} \mathrm{C}$ for 10 to 14 days. Inital cell suspensions ranged from $1(E+4)$ to $1(E+6)$ cells/mL. Catfish spleen and kidney cells were exposed to $250 \mathrm{R}$ of $\mathrm{x}$-ray irradiation and cultured for 10 days.

\subsection{RESULTS}

\subsubsection{In vivo Exposures}

\subsubsection{Benzene Exposures}

BTood samples were collected on six separate occasions, including the baseline sampling. Slides from the September 1985 sampling showed a high degree of clumping, which prevented the quantification of cells. There was no difference between the relative distribution of erythrocytes, lymphocytes, and monocytes/granulocytes for benzene-exposed fish and the control group of fish over the 8 -month study period (Table 10). The decrease in erythrocytes and increase in lymphocytes observed in samples taken at 5 months and 8 months may be attributed to differences in methods by the technicians reading the slides.

A comparison of the technicians' evaluation of the same slides supports this position (Table 11). Technician No. 1 read the slides for the baseline sampling and months 1 and 2, while technician No. 2 read the slides for months 5 and 8 . Technician No. 1 consistently counted about $5 \%$ fewer erythrocytes and $5 \%$ more lymphocytes than technician No. 2 . The most. important observation was that neither technician detected a difference between the control treatment and the exposure group.

\subsubsection{Pristane and Pristane/Benzene Injected Fish}

Anesthetized catfish were sampled by injecting the fish with $0.5 \mathrm{~mL}$ of saline then removing the saline by in situ rinsing of the peritonea cavity. The saline was then examined and cultured for cells. The 
TABLE 10. Distribution (\%+1.0 SD) of Cell Types in Benzene-Exposed Catfish

\begin{tabular}{|c|c|c|c|c|c|}
\hline Group & $\underline{N}$ & Erythrocytes & Lymphocytes & $\begin{array}{c}\text { Monocytes- } \\
\text { Granulocytes }\end{array}$ & Other \\
\hline \multicolumn{6}{|c|}{ Inital bleeding } \\
\hline Baseline & 40 & $\begin{array}{r}92.3 \\
1.6\end{array}$ & $\begin{array}{l}6.4 \\
1.6\end{array}$ & $\begin{array}{l}0.6 \\
0.2\end{array}$ & $\begin{array}{l}0.7 \\
0.2\end{array}$ \\
\hline
\end{tabular}

Month 1

\begin{tabular}{lrrrrr}
\hline Benzene & 25 & 92.6 & 5.4 & 1.1 & 1.2 \\
& & 1.0 & 0.7 & 1.4 & 0.5 \\
Control & 10 & 90.2 & 7.1 & 1.3 & 1.2 \\
& & 1.3 & 1.0 & 0.4 & 0.5
\end{tabular}

Month 2

\begin{tabular}{lrrrrr}
\hline Benzene & 26 & 91.1 & 7.1 & 0.8 & 1.0 \\
& & 1.2 & 1.3 & 0.3 & 0.4 \\
Control & 10 & 93.6 & 5.0 & 0.6 & 1.0 \\
& & 0.7 & 0.6 & 0.1 & 0.4
\end{tabular}

Month 5

\begin{tabular}{lrrrrr}
\hline Benzene & 23 & 80.8 & 16.2 & 1.4 & 1.6 \\
& & 7.1 & 7.5 & 1.9 & 1.6 \\
Control & 10 & 79.4 & 15.1 & 2.5 & 2.7 \\
& & 7.2 & 6.2 & 1.6 & 2.9
\end{tabular}

Month 8

\begin{tabular}{lrrrrr}
\hline Benzene & 21 & 82.9 & 15.6 & 1.0 & 0.5 \\
& & 3.9 & 4.4 & 0.8 & 0.6 \\
Control & 6 & 84.2 & 14.5 & 0.4 & 1.1 \\
& & 3.3 & 3.0 & 0.3 & 1.4
\end{tabular}

effectiveness of this method was variable, with recovery of injected saline ranging from $>20 \%$ to $90 \%$ (Table 12). Generally, the smaller the volume of saline recovered the higher the concentration of cells. The peritoneal cells were quantified by hemacytometry when cell densities were on the order of $10(E+5) c e 11 \mathrm{~s} / \mathrm{mL}$ or less. 
TABLE 11. Comparison of Cel1 Counts (\%) Made by Technician No. 1 and No. 2 From the Same S? ides

\begin{tabular}{|c|c|c|c|c|c|c|c|c|}
\hline Slide & \multicolumn{2}{|c|}{ Erythrocytes } & \multicolumn{2}{|c|}{ Lymphocytes } & \multicolumn{2}{|c|}{$\begin{array}{l}\text { Monocytes- } \\
\text { Granulocytes }\end{array}$} & \multicolumn{2}{|c|}{ Other } \\
\hline I.D. \# & No. 1 & №. 2 & No. 1 & No. 2 & No. 1 & No. 2 & No. 1 & №. 2 \\
\hline $2070-41$ & 95 & 87 & 4 & 8 & 1 & 2 & 0.5 & 2.8 \\
\hline $2070-64$ & 92 & 87 & 6 & 12 & 0.5 & 0.9 & 1.7 & 0 \\
\hline $2070-47$ & 93 & 88 & 5 & 10.5 & 0.3 & 1.2 & 1.5 & 0.4 \\
\hline $2070-1$ & 89 & 85 & 10 & 14.8 & 0.5 & 0.4 & 0.7 & 0 \\
\hline
\end{tabular}

The primary objective of these exposures was to generate viable cell cultures from the peritoneal washes. As before, cell cultures died within 10 to 14 days after sampling. Slides prepared from the peritoneal washes showed numerous macrophages, monocytes, and lymphocytes. Not all slides were evaluated; however, those that were did not have any cells showing hyperchromaticism, which would be indicative of transformed cells. The distribution of cell types was not determined because of the death of the cell cultures. Distribution was not possible to determine with samples that had low recovery (i.e., high volume and low cell density).

As part of the in vivo benzene exposures, a group of nine fish were selected to receive pristane injections. The distribution of blood cell types paralleled the control group and the remaining catfish that had been exposed to waterborne benzene (Table 13).

The cell cultures grew for the first 10 to 14 days of culture, then al1 cultures died. The pattern of growth and death was similar to the pattern observed in previous attempts to culture catfish cells.

\subsubsection{In vitro Exposures}

\subsubsection{Cell Culture}

Attempts at an extended culture of catfish cells taken from the kidney or spleen were unsuccessful. The general pattern of growth was characterized by a period of apparent growth during the first 96 to 
TABLE 12. Peritoneal Sampling of Pristane- and Pristane/BenzeneInjected Catfish (fish weight, length, and sampling efficiency)

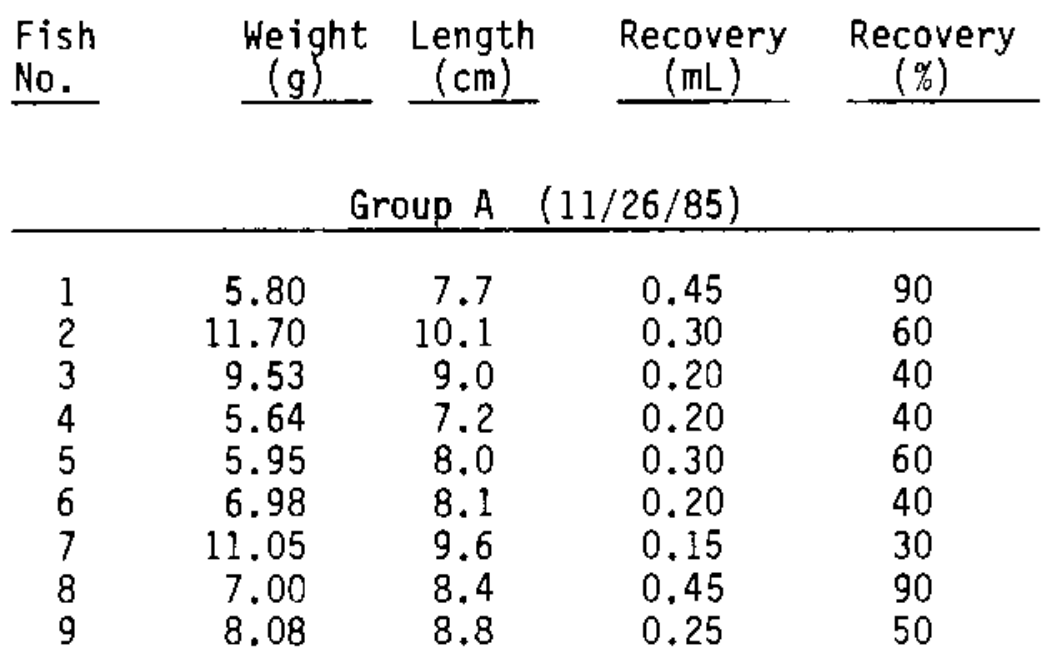

Group B $(11 / 27 / 85)$

\begin{tabular}{rrrrr}
\hline 1 & 9.02 & 9.2 & 0.38 & 76 \\
2 & 7.17 & 8.5 & 0.20 & 40 \\
3 & 6.32 & 8.0 & 0.25 & 50 \\
4 & 7.75 & 8.6 & 0.10 & 20 \\
5 & 5.63 & 7.7 & 0.40 & 80 \\
6 & 6.22 & 8.2 & 0.31 & 62 \\
7 & 4.28 & 7.1 & 0.35 & 70 \\
8 & 13.91 & 10.2 & 0.18 & 36 \\
9 & 15.89 & 10.8 & 0.20 & 40 \\
& & & & \\
& & & & \\
& & Group C (a) & $(11 / 29 / 85)$ & \\
2 & 6.61 & 7.9 & 0.37 & 74 \\
4 & 5.20 & 7.3 & 0.40 & 80 \\
10 & 10.73 & 8.9 & 0.14 & 28 \\
13 & 9.57 & 8.7 & $>0.10$ & $>20$ \\
16 & 7.14 & 7.9 & 0.17 & 34 \\
18 & 5.01 & 7.3 & 0.15 & 30 \\
27 & 4.16 & 7.2 & 0.42 & 84 \\
32 & 11.14 & 9.9 & 0.25 & 50
\end{tabular}

(a) Fish identification numbers correspond to branding numbers assigned to the fish in June. 
TABLE 13. Blood Ce11 Distribution of Catfish Exposed to Benzene, Exposed to Benzene and Injected with Pristane, and Control Fish

\begin{tabular}{|c|c|c|c|c|c|}
\hline Group & $\underline{\mathrm{N}}$ & Erythrocytes & Lymphocytes & $\begin{array}{c}\text { Monocytes- } \\
\text { Granulocytes }\end{array}$ & Other \\
\hline \multicolumn{6}{|c|}{ Month 1} \\
\hline Benzene ${ }^{(a)}$ & 9 & $\begin{array}{r}92.2 \\
0.9\end{array}$ & $\begin{array}{l}5.5 \\
0.6\end{array}$ & $\begin{array}{l}1.1 \\
0.3\end{array}$ & $\begin{array}{l}1.2 \\
0.4\end{array}$ \\
\hline Control & 10 & $\begin{array}{r}90.2 \\
1.3\end{array}$ & $\begin{array}{l}7.1 \\
1.0\end{array}$ & $\begin{array}{l}1.3 \\
0.4\end{array}$ & $\begin{array}{l}1.2 \\
0.5\end{array}$ \\
\hline
\end{tabular}

Month 2

\begin{tabular}{lrrrrr}
\hline Benzene & 26 & 91.1 & 7.1 & 0.8 & 1.0 \\
& & 1.2 & 1.3 & 0.3 & 0.4 \\
Pristane & 9 & 91.4 & 6.8 & 0.7 & 1.1 \\
& & 1.3 & 1.6 & 0.2 & 0.5 \\
Control & 10 & 93.6 & 5.0 & 0.6 & 1.0 \\
& & 0.7 & 0.6 & 0.1 & 0.4 \\
& & & Month 5 & & \\
\hline Benzene & 23 & 80.8 & 16.2 & 1.4 & 1.6 \\
& & 7.1 & 7.5 & 1.9 & 1.6 \\
Pristane & 9 & 80.1 & 15.1 & 2.4 & 2.4 \\
& & 6.3 & 8.1 & 2.1 & 2.3 \\
Control & 10 & 79.4 & 15.1 & 2.5 & 2.7 \\
& & 7.2 & 6.2 & 1.6 & 2.9 \\
& & & Month 8 & & \\
\hline Benzene & 21 & 82.9 & 15.6 & 1.0 & 0.5 \\
& & 3.9 & 4.4 & 0.8 & 0.6 \\
Pristane & 5 & 81.7 & 10.6 & 5.0 & 2.6 \\
& & 8.1 & 6.2 & 6.0 & 2.5 \\
Control & 6 & 84.2 & 14.5 & 0.4 & 1.1 \\
& & 3.3 & 3.0 & 0.3 & 1.4 \\
& & & & &
\end{tabular}

(a) Pre-injection baseline of nine fish used for pristane injection (see Table 1 for initial baseline distribution and distribution of entire group of fish exposed to benzene). 
72 hours, followed by a period of senescence for the next 3 to 5 days, and finally death as indicated by the lysis of cells. In selected cultures, masses (possibly clones) of cells were observed that appeared to be derived from a single cell. These cell masses were not observed after 7 days of culture. In one sample contaminated with erythrocytes enhanced growth was noted, suggesting that a feeder cell line may be necessary for an extended culture of lymphocytes. Enhanced growth was also noted when pieces of whoie tissue (explants) were cultured, although the cell cultures died within 10 to 14 days.

\subsubsection{Benzene Exposures}

Some exposures were performed to transform catfish hematopoietic cells. Benzene solutions $(0.1 \mathrm{mM})$ were prepared, although the cell yieid was insufficient for paired exposures of benzene-dosed and control media for the spleen cells. Kidney cells were run in both control and benzene-dosed media. Initially, the cultures in a 11 treatments grew through the initial 96 hours. Visual observation of the cells indicated no apparent differences in growth between the benzene-exposed and control media treatments.

Initially clones of cells were observed in both treatments, although the viability of these clones was short lived. At about 12 to 14 days of culture (three transfers), the cultures died.

\subsubsection{X-ray Exposure}

A single exposure of catfish hematopoitic cells to $250 \mathrm{R}$ was conducted in an attempt to produce a transformed cell line. Initial cell suspensions following irradiation were set at $1(E+6)$ cells $/ \mathrm{mL}$. The cells appeared to be viable for about 7 days and then appeared to enter a period of senescence and died.

There are several possible explanations for the death of the cultured cells. The density of cells in the culture may have been too low, although death has occurred in cultures with cell densities on the order of $1(E+6)$ celis/mL. Two of the saline peritoneal samples were contaminated with blood. The red blood cells settled into a heavy iayer on the bottom of the 
plate wells. These cultures appeared to have clones of cells growing when they were initially examined, although they too expired after the initial series of transfers. It may be worthwhile to use a feeder cell line such as channel catfish ovary (CCO) (Bowser and Plumb 1980). It is also possible that the L-15 media may not support the growth of catfish plasmacytes. Other media may be more suitable, such as Eagle's minimal essential medium or RPMI 1640 . The culture temperature currently used $\left(20^{\circ} \mathrm{C}\right)$ may not be the optimum temperature for cell growth. The optimum temperature for growth of $\mathrm{CCO}$ cells was $<30^{\circ} \mathrm{C}$ with doubling times of 12 hours at $35^{\circ} \mathrm{C}$ and 15.2 hours at $30^{\circ} \mathrm{C}$ (Bowser and Plumb 1980). The doubling time at $20^{\circ} \mathrm{C}$ was 2.6 days. Growth temperature and different media should be tested to determine optimum conditions for growth. 


\subsection{CONCLUSIONS AND RECOMMENDATIONS}

The objective of the research with ochratoxin and T2 toxin was to demonstrate the production of antibodies against the toxins. Experiments with both toxins indicated that channel catfish did not produce a polyclonal response against the hapenized mycotoxins. This conciusion does not necessarly imply that catfish are unable to produce antibodies against haptenized mycotoxins. In both experiments, haptenized toxins were purchased from Sigma Chemical Company, and great difficulty was encountered in dissolving the conjugated compounds in saline for vaccination and ELISA. In the undissolved state, the conjugates may have been more immunogenic than in the dissolved state; however, the undissolved conjugates could not be used to precoat Immulon-2 plates for ELISA. The use of cross-linked T2-BSA and T2-KLH introduces an important unquantified variable. The catfish were inmunized with the lyophylized and resuspended form of the conjugate (i.e., a suspension) that may be significantly different than the conjugated form used to precoat the wells for ELISA. This type of immunization not only may have affected the overall level of activity, but could have eliminated the detection of the haptenized molecule depending on the nature and extent of denaturation caused by the cross-linking reagent and the resulting differences between the suspension used to inject the catfish.

Attempts to culture catfish hematopoietic cells for extended periods were unsuccessful. The media used to culture the cells had been used previously to culture teleost cell lines (personal communication, Ralph Stahl, DuPont de Nemours, Wilmington, DE). Had the attempted exposures been successful at transforming the cells, it is probable that the cells would have continued to grow as the nontransformed cells died out. The inability to simply culture catfish cells (peritoneal cells, spleenocytes and kidney cells) must be resolved before work can progress in this area. The benzene exposures failed to induce any abberation in the general distribution of blood cells. The approach of using chronic, long-term exposures to benzene may not have been the best approach. Rather, acute exposures at near lethal concentrations may have been more successful at 
inducing neoplastic transformations. Alternatively, stronger genotoxic agents could have been tested, both in vitro and in vivo. In vivo exposures are necessary for compounds that require metabolic activation. Simultaneous exposure of catfish lymphocytes to mitogens and carcinogens could also enhance the potential to induce a myelogenous cell line.

An alternative approach worth considering is to amend culture media with mitogens to stimulate the growth of 1ymphocytes. Carcinogenic agents may be added during or after the addition of mitogens to increase the probability of inducing a plasmacytoma. 


\subsection{REFERENCES}

Bowser, P. R., and J. A. Plumb. 1980. "Growth Rates of a New Cell Line From Channel Catfish Ovary and Channel Catfish Virus Replication at Different Temperatures." Can. J. Fish. Aquat. Sci. 37:871-873.

Chu, F. S., F. C. C. Chang, and R. D. Hinsdill. 1976. "Production of Antibody Against 0chratoxin A." Appl. Environ. Microbiol. 31:831-835.

Voller, A., D. E. Bidwel1, and A. Bartlett. 1979. The Enzyme Linked Immunosorbent Assay (ELISA). Dynatech Laboratories, Inc., ATexandria, Virginia. 


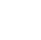

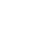

. 


\section{DISTRIBUTION}

No. of

Copies

OFFSITE

30 DOE Technical Information Center

5 Dr. Robert S. Anderson

Chesapeake Biological Laboratory University of Maryland

Box 38

Solomon, MD 20688

Dr. Helen McCammon

Dffice of Health and

Environmental Research

U.S. Department of Energy

Washington, D.C. 20545
No. of

Copies

ONSITE
DOE Richland Operations Office

J. J. Sutey

26 Pacific Northwest Laboratorv

K. A. Boraeson

A. K. Baldwin

D. D. Dauble

D. W. Dragnich

P. C. Hayes

P. J. Mellinger

T. L. Page

T. M. Poston (10)

J. A. Sottlemyre

J. A. Strand

Technical Report Files (5)

Publishing Coordination (?) 
. 